\title{
Reliability and validity of the Turkish version of oral health impact profile for edentulous subjects
}

\section{Purpose}

The validated translations of the OHIP-EDENT exist in different languages; however, there is no reliable and validated Turkish translation. The present study was conducted to evaluate the reliability and to validate the Oral Health Impact Profile in edentulous subjects translated to Turkish (OHIP-EDENT-T).

\section{Materials and Methods}

The study sample included 104 conventional complete denture wearers (58 women and 46 men, mean age: $61.13 \pm 9.43$ years). The original English version of OHIPEDENT was translated into Turkish using a forward-backward method and applied to the subjects. The reliability of the OHIP-EDENT-T was evaluated using internal consistency and the test-retest method. Validity was determined as construct and convergent validity. The construct validity of OHIP-EDENT-T was assessed using exploratory and confirmatory factor analysis.

\section{Results}

The Cronbach's alpha value for OHIP-EDENT-T was 0.890. The intraclass correlation coefficient (ICC) was 0.749 for the OHIP-EDENT-T total score, and ICCs for the subscales ranged from $0.630(95 \% \mathrm{Cl}=0.501-0.823)$ to $0.859(95 \% \mathrm{Cl}=0.531-0.897)$, indicating good to excellent agreement. The Kaiser-Meyer-Olkin value for sampling adequacy was 0.820 and results of Bartlett's sphericity test indicated statistical significance $(x 2=1139.767 ; \mathrm{df}=171, \mathrm{p}=0.001)$. This showed that factorial analysis could be applied to the data set. The three-factor structure of the scale explained $81.1 \%$ of the observed variance. The agreement of the three-factor solution was further tested with confirmatory factor analysis, and the fit index was found to be acceptable (chi-square fit test $=1.449, \mathrm{RMSEA}=0.040, \mathrm{GFI}=0.94, \mathrm{CFI}=0.93$ ).

\section{Conclusion}

Within the limitations of this study, it can be concluded that OHIP-EDENT-T is a valid and reliable instrument for evaluating the quality of life of edentulous patients.

Keywords: Oral-health related quality of life, OHIP, OHIP-EDENT, Edentulous, Complete denture

\section{Introduction}

The increase in the life expectancy has been associated with tooth loss (1). In Turkey, the prevalence of edentulism is on the rise (2) and this affects the main functional activities of edentulous patients (3). The Oral Health-Related Quality-of-Life (OHRQoL) is a multi-dimensional construct that aims to collect information concerning the patient's subjective assessment of his/ her oral health, including functional as well as psycho-social well-being, sense of self, expectations and treatment satisfaction (4). Although both fixed and removable implant-supported prostheses have been reported to increase OHRQoL and patient satisfaction when compared to complete dentures (CDs) (5), CDs continue to be the most common treatment option for edentulism (6).

\author{
Canan Bural ${ }^{1} \mathbb{D}$, \\ Onur Geckili' ${ }^{1}$, \\ Ozge Erdogan ${ }^{2}$, \\ Kıvanc Bektas-Kayhan ${ }^{3}$ (D), \\ Suleyman Cagatay Dayan ${ }^{4}$
}

ORCID IDs of the authors: C.B. 0000-0003-2684-5506; O.G. 0000-0002-7852-3915; O.E. 0000-0002-7584-3729; K.B.K. 0000-0001-7149-9230; C.D. 0000-0003-3081-9618

'Istanbul University, Faculty of Dentistry, Department of Prosthodontics, Istanbul, Turkey ${ }^{2}$ Private Practice, Istanbul, Turkey

${ }^{3}$ Istanbul University, Faculty of Dentistry, Department of Oral and Maxillofacial Surgery, Istanbul, Turkey

${ }^{4}$ Istanbul University - Cerrahpaşa, Vocational School of Health Services, Istanbul, Turkey

Corresponding Author: Süleyman Çağatay Dayan E-mail: suleyman.dayan@istanbul.edu.tr Received: 3 August 2020 Revised: 16 September 2020 Accepted: 12 November 2020 
OHRQoL scales are score-based tools for evaluating the effect of dental treatment on oral health and quality-of-life (7-11). One of the most popular OHRQoL instruments, the Oral Health Impact Profile (OHIP) provides a detailed analysis of OHRQoL based on the conceptual model of oral health described by Locker that utilizes the World Health Organization (WHO) International Classification of Impairments, Disabilities and Handicaps (12-14). The OHIP comprises of 49 questions grouped under 7 subdomains, namely: functional limitation, physical pain, psychological discomfort, physical disability, psychological disability, social disability and handicap. OHIP is a realiable and valid instrument, however, it is also long and difficult to complete $(15,16)$. A shorter, more patient-friendly 14item version of the (OHIP-14), developed by Slade (14), covers the same 7 domains as the original OHIP. This version demonstrated acceptable validity, therefore, it is less time-consuming for researchers and easier to complete for patients. However, some parts of the OHIP-14 are inappropriate for CRDP wearers and the floor effect limits its ability to detect improvements in CRDP wearers following clinical intervention (16). To address these issues, Allen and Locker (16) implemented the OHIP-EDENT, a 19-statement version that covers the same domains as the OHIP, that can detect changes in OHRQoL before and after insertion of new CRDPs. Since the OHIP-EDENT can be used to evaluate negative impacts specifically related to edentulous patients, it can provide additional data that might be useful in developing effective interventions for edentulous patients (17).

Validated translations of the OHIP-EDENT exist in Portuguese, Japanese, Spanish, Chinese and Nepalese; however; there is no reliable and validated Turkish translation (17-21). Therefore, recent studies on the edentulous Turkish population have used the Turkish version of the OHIP-14, which has been noted as a limitation (22-26). Therefore, the aim of the present study was to translate the OHIP-EDENT into Turkish and to assess the reliability and validity of this translated version (OHIP-EDENT-T).

\section{Patients and Methods}

\section{Participants and eligibility criteria}

This study was approved by the Ethics Committee of the Istanbul University Faculty of Medicine (Approval No. 18205), and written informed consents were obtained from all participants. Based on a recommended minimum of 5-10 patients per item for instrument analysis (27) (i.e. 95 participants for the 19-item questionnaire), and adding $10 \%$ to account for possible drop-outs, 104 edentulous individuals (58 female, 46 male, age range: 39-87 years; mean age: $61.13 \pm$ 9.43) were recruited consecutively among patients attending the Istanbul University, Faculty of Dentistry, Department of Prosthodontics for CD treatment. To be included in the current study, the subjects had to be adult, consent to participate, be born, raised and educated within the national borders of Turkey, and have the cognitive skills and literacy to complete the study forms. Individuals who were unable to understand the OHIP-EDENT-T questions were not invited to the study.

\section{Complete dentures}

Conventional maxillary and mandibular dentures were fabricated using standard prosthetic method that involved balanced articulation with anatomic acrylic resin teeth (Enigma; Davis Schottlander \& Davis, Tonawanda, NY, USA) and maximal extension of the denture borders using functional impression methods by 5 prosthodontists who were blinded to the study protocol (28).

\section{Translation}

The original OHIP-EDENT questionnaire comprises of 19 items grouped under 7 domain as follows: 1-functional limitation (3 items), 2- physical pain (4 items), 3- psychological discomfort (2 items), 4-physical disability (3 items), 5-psychological disability (2 items), 6- social disability (3 items) and 7-handicap (2 items) (17). Participants rate the frequency with which their daily activities are affected by oral health-related problems associated with denture use on a scale of 0-4 (0: Never; 1: Hardly ever; 2: Occasionally; 3: Fairly often; 4: Very often). OHRQoL impairment is characterized by the the sum of the individual items that ranges from 0 to 76. Higher scores indicate greater impairment. The OHIPEDENT was translated into Turkish by a dentist fluent in both English and Turkish. The translated version (OHIP-EDENT-T) was reviewed by six other dentists, and the conceptual equivalence between the original inventory and the translated version was checked by an independent, professional translator who has back-translated the scale (8).

\section{Questionnaire administration}

Following an average of 4-week of functional adaptation and adjustment period during which the subjects wore the same dentures, The OHIP-EDENT-T (Figure 1), the global question (see convergent validity section below) and a demographic form were handed out to the patients. Subjects filled the forms alone in a quiet room in the morning hours with no time restriction. 35 randomly selected participants were re-tested after two weeks.

\section{Reliability}

Internal consistency of the OHIP-EDENT-T was assessed by calculating Cronbach's alpha values. Test-retest reliability was evaluated by calculating intraclass correlation coefficients (ICC) and 95\% confidence intervals (CI) for the OHIPEDENT-T. Cronbach's alpha values range from 0.0-1.0, with a value of 0.7 or higher considered reliable (29). Intra-class correlation (ICC) scores that indicate varying levels of agreement were interpreted as follows: <0.40: poor to fair; $0.41-$ 0.60: moderate; 0.61-0.80: good: >0.80: excellent (30).

\section{Validity}

Construct validity of the OHIP-EDENT-T was assessed using exploratory factorial analysis. Bartlett's sphericity and Kaiser-Meyer-Olkin (KMO) tests were conducted to explore possible significant correlations among the OHIP-EDENT-T items, with factor loadings of $>0.40$ considered significant (31). 
1. Dişlerinizde, ağzınızda veya takma dişlerinizde bir sorun olduğu için yemek çiğnemekte zorluk çektiniz mi?

2. Dişlerinize veya takma dişlerinize yemek kaçtı mı?

3. Takma dişlerinizin yerine tam oturmadığını hissediyor musunuz?

4. Ag̈zınızda acı duydunuz mu?

5. Dişlerinizde, ağzınızda veya takma dişlerinizde bir sorun olduğu için yemek yerken rahatsızlık duydunuz mu?

6. Ag̈zınızda acıyan yerler var mı?

7. Takma dişleriniz rahatsızlık verdi mi?

8. Dişlerinizle ilgili sorununuz var $\mathrm{mI}$ ?

9. Dişleriniz, ağzınız veya takma dişlerinizin farkında olarak mı yaşıyorsunuz?

10. Dişleriniz, ağzınız veya takma dişlerinizle ilgili bir sorun nedeniyle bazı yemekleri yemekten çekindiniz mi?

11. Takma dişlerinizle ilgili sorun nedeniyle yemek yiyemediğiniz oluyor mu?

12. Dişleriniz, ağzınız veya takma dişlerinizle ilgili bir sorun nedeniyle yemek yemeyi yarıda bıraktığınız oldu mu?

13. Dişleriniz, ağzınız veya takma dişlerinizle ilgili bir sorun nedeniyle üzülüyor musunuz?

14. Dişleriniz, ağzınız veya takma dişlerinizle ilgili bir sorun nedeniyle utanıyor musunuz?

15. Dişleriniz, ağzınız veya takma dişlerinizle ilgili bir sorun nedeniyle dışarı çıkmaktan kaçındığınız oldu mu?

16. Dişleriniz, ağzınız veya takma dişlerinizle ilgili bir sorun nedeniyle eşinize veya ailenize karşı daha az hoşgörülü müsünüz?

17. Dişleriniz, ağzınız veya takma dişlerinizle ilgili bir sorun nedeniyle başkalarını rahatsız ediyor musunuz?

18. Dişleriniz, ağzınız veya takma dişlerinizle ilgili bir sorun nedeniyle başkaları ile birlikte olmaktan zevk almadığınız oluyor mu?

19. Dişleriniz, ağzınız veya takma dişlerinizle ilgili bir sorun nedeniyle genelde hayatın daha az tatmin edici olduğunu düşünüyor musunuz?

Figure 1. Turkish translation of the OHIP-EDENT (OHIP-EDENT-T). The rating scale for each item is as follows:

0: Hiç bir zaman, 1: Ender, 2: Bazen, 3: Sık, 4: Çok sık.

\section{Convergent validity}

In line with previous studies, after responding to the OHIPEDENT-T, participants were asked an extra-global question ("Are you satisfied with the use of complete dentures") with 5 possible responses (1-"very satisfied", 2-" 'satisfied," 3-"fair," 4-"dissatisfied", 5-"very dissatisfied") in order to examine convergent validity $(17,21)$. The convergent validity was assessed by examining the correlation between OHIP-EDENT-T subscale scores and the global question, with correlation levels rated as follows: <0.20: poor; 0.21-0.40: fair; 0.41-0.60: good; 0.61-0.80: very good; >0.81: excellent (32).

\section{Statistical analysis}

Data analysis was performed using the Statistical Package for Social Sciences (SPSS Inc., Release 15.0 for Windows, Chicago, IL, USA). In addition, the factorial model according to the results of exploratory factor analysis was verified by confirma- tory factor analysis (IBM SPSS Amos 21.0; IBM Corp, Armonk, NY, USA). The current study used the following fit indexes: chisquare fit test (acceptable value $\leq 3$ ), a root-meansquare error of approximation (RMSEA, acceptable value $\leq .08$ ), goodness of fit index (GFI, acceptable value $\geq .85$ ) and comparative fit index (CFI, acceptable value $\geq .90)$. The confidence level was set to $95 \%$ and $p<0.05$ was considered significant.

\section{Results}

Demographic data of participants was presented in Table 1.

Reliability

Table 2 shows the internal consistency of the multi-item scales. Cronbach's alpha for the OHIP-EDENT-T total score was 0.890 . Cronbach's alpha values for the subscales ranged from 0.714 for "Physical pain" to 0.883 for "Psychological disability." All subscales exceeded the minimum reliability stan- 
dard of 0.70. The ICC was 0.749 for the OHIP-EDENT-T total score, and ICCs for the subscales ranged from $0.630(95 \% \mathrm{CI}$ $=0.501-0.823)$ to $0.859(95 \% \mathrm{Cl}=0.531-0.897)$, which indicates good to excellent agreement.

Validity

As KMO value for sampling adequacy was 0.820 and Bartlett's sphericity test indicated statistical significance ( $x 2=1139.767 ; d f=171, p=0.001$ ) factorial analysis could be applied to the data set. The results of factor analysis for all subscales are given in Table 3. Factor loadings were above 0.40 for all items. $81.1 \%$ of total variance was explained by three factors, namely: Physical impact (Functional limita-

Table 1. The distribution of the demographic data of the participants.

\begin{tabular}{llll}
\hline & & $\mathbf{n}$ & $\%$ \\
\hline Gender & Women & 58 & 55.8 \\
& Men & 46 & 44.2 \\
Health & Poor & 12 & 11.6 \\
& Moderate & 45 & 43.2 \\
Marital & Good & 47 & 45,2 \\
status & Single & 27 & 25.9 \\
Living & Married & 77 & 74.1 \\
status & Wlone & 17 & 16.3 \\
Working & Retired & 87 & 83.7 \\
status & Working & 83 & 79.8 \\
Monthly & Low & 21 & 20.2 \\
income & Moderate & 23 & 22.1 \\
level & High & 30 & 28.9 \\
& University & 51 & 49.0 \\
Educational & High school & 15 & 14.4 \\
level & Middle school & 54 & 32.7 \\
& or under & & 52.9 \\
& & & \\
\hline
\end{tabular}

tion, Physical pain, Physical disability); Psychological impact (Psychological discomfort, Psychological disability); and Social impact (Social disability, Handicap). OHIP-EDENT-T total and subscale scores significantly correlated with the global question (rs: 0.645-0.742), demonstrating good to excellent convergent validity (Table 4).

When the fit index values were examined, the current study have found that the results were acceptable and in good agreement. The results from the fit indexes were; for chisquare fit test 1.449 , for RMSEA 0.040 , for GFI 0.94, for CFI 0.93.

\section{Discussion}

The OHIP-EDENT questionnaire has become the gold standard for reporting patient centered quality of life in edentulous patient (33). The questionnaire has been translated into Portuguese, Japanese, Spanish, Chinese and Nepalese and the reliability of these culturally-adapted versions have been evaluated (17-21). However, the present study is the first to examine the reliability and validity of a Turkish version of the OHIP-EDENT, the OHIP-EDENT-T.

Previous studies have reported that the Cronbach's alpha values for the OHIP-EDENT varied between 0.785 and 0.972 $(17,21)$. This inconsistency, such as the one between Nepali as well as Chinese versions of the OHIP-EDENT, have been attributed to the differences in sample sizes $(17,21)$. Cronbach's coefficient alpha of OHIP-EDENT-T was 0.89, which indicates that this scale is able to measure a theoretical construct with good internal consistency and to reliably detect changes in the OHRQoL of edentulous subjects. The corrected item-total correlation coefficients were above 0.20 which shows the consistency of the items in the scale. Good internal consistency was further clarified by ICC values $(0.749$; (95\% Cl $=0.567-0.896)$, indicating test-retest reliability remains stable over time.

Previous studies evaluating the OHRQoL of new denture wearers have reported OHIP-EDENT scores of 14.91 and 16.23. The present findings demonstrated that the mean OHIP-EDENT-T score was 14.59, which is in accordance with those reported previously (19,34). A systematic review and meta-analysis of the baseline OHIP-EDENT scores determined 28.63 (95\% Cl, range: $21.93-35.34$ ) to be the pre-treat-

Table 2. Cronbach's coefficient alpha values and test-retest reliability of the OHIP-EDENT-T.

\begin{tabular}{|c|c|c|c|c|c|}
\hline & & $\begin{array}{c}\text { OHIP EDENT-T } \\
\text { Mean } \pm \text { Standard Deviation }\end{array}$ & $\begin{array}{l}\text { Corrected item total } \\
\text { correlation }(n=104)\end{array}$ & $\begin{array}{l}\text { Test-retest (ICC) } \\
\qquad(n=35)\end{array}$ & $95 \% \mathrm{Cl}$ \\
\hline \multirow[t]{3}{*}{ Physical impact } & $\begin{array}{l}\text { Functional } \\
\text { limitation }\end{array}$ & $3.65 \pm 2.88$ & 0.813 & 0.793 & $0.453-0.815$ \\
\hline & Physical pain & $4.19 \pm 3.67$ & 0.714 & 0.645 & $0.417-0.793$ \\
\hline & Physical disability & $2.37 \pm 2.84$ & 0.819 & 0.630 & $0.501-0.823$ \\
\hline \multirow[t]{2}{*}{$\begin{array}{l}\text { Psychological } \\
\text { impact }\end{array}$} & $\begin{array}{l}\text { Psychological } \\
\text { discomfort }\end{array}$ & $2.16 \pm 2.22$ & 0.765 & 0.684 & $0.449-0.804$ \\
\hline & $\begin{array}{l}\text { Psychological } \\
\text { disability }\end{array}$ & $1.01 \pm 1.71$ & 0.883 & 0.859 & $0.531-0.897$ \\
\hline \multirow[t]{3}{*}{ Social impact } & Social disability & $0.64 \pm 1.79$ & 0.841 & 0.724 & $0.597-0.876$ \\
\hline & Handicap & $0.57 \pm 1.42$ & 0.839 & 0.786 & $0.550-0.861$ \\
\hline & $\begin{array}{l}\text { Total OHIP- } \\
\text { EDENT-T }\end{array}$ & $14.59 \pm 13.09$ & 0.890 & 0.749 & $0.567-0.896$ \\
\hline
\end{tabular}


ment baseline for edentulous patients. Although the present study did not record pre-treatment scores, the enormous difference between the baseline OHIP-EDENT scores reported by meta-analysis and the post-treatment scores calculated in the present study suggest that improvements

Table 3. Exploratory factor analysis of OHIP-EDENT-T.

$\begin{array}{ccc}\text { Factor 1: } & \text { Factor 2: } & \text { Factor 3: } \\ \text { Physical } & \text { Psychological } & \text { Social } \\ \text { impact } & \text { impact } & \text { impact }\end{array}$

Factor 1:

\begin{tabular}{ll}
\hline Physical impact & \\
\hline 1. Chewing difficulty & 0.651 \\
\hline 2. Food catching & 0.455 \\
\hline 3. Dentures not fitting & 0.515 \\
\hline $\begin{array}{l}\text { 4. Aching sensation } \\
\text { 5. Uncomfortable to } \\
\text { eat }\end{array}$ & 0.586 \\
\hline $\begin{array}{l}\text { 6. Sore spots } \\
\text { 7.Uncomfortable } \\
\text { dentures }\end{array}$ & 0.782 \\
\hline $\begin{array}{l}\text { 10. Avoids eating } \\
\text { 11. Unable to eat }\end{array}$ & 0.471 \\
\hline \begin{tabular}{l} 
12. Interrupts meals \\
\hline
\end{tabular} & 0.582 \\
\hline
\end{tabular}

Factor 2:

\begin{tabular}{ll}
\hline Psychological impact & \\
\hline 8. Worried & 0.784 \\
\hline 9. Self-conscious & 0.671 \\
\hline 13. Upset & 0.717 \\
\hline 14.Been embarrassed & 0.434 \\
\hline
\end{tabular}

\section{Factor 3:}

\begin{tabular}{|c|c|c|c|}
\hline \\
\hline \multicolumn{3}{|l|}{$\begin{array}{l}\text { Social impact } \\
\text { 15. Avoided going out }\end{array}$} & 0.749 \\
\hline \multicolumn{3}{|l|}{ 16. Less tolerant } & 0.724 \\
\hline \multicolumn{3}{|l|}{ 17. Irritable } & 0.859 \\
\hline \multicolumn{3}{|l|}{$\begin{array}{l}\text { 18.Unable to enjoy } \\
\text { company }\end{array}$} & 0.881 \\
\hline \multicolumn{3}{|l|}{ 19.Life unsatisfying } & 0.481 \\
\hline$\%$ variance & 45.5 & 25.4 & 10.2 \\
\hline Total variance (\%) & & 81.1 & \\
\hline
\end{tabular}

Table 4. Convergent validity of the OHIP-EDENT-T: correlations between subscale scores with global oral health rating (Spearman's rank correlation coefficient. ${ }^{*} p<0.01$ ).

\begin{tabular}{lcc} 
Subscale & Rs & $\mathbf{9 5 \%} \mathbf{C l}$ \\
\hline Total Score & 0.734 & 0.590 to $0.831 *$ \\
\hline Subscales & & \\
\hline Physical impact & 0.711 & 0.560 to $0.820 *$ \\
\hline Psychological impact & 0.742 & 0.650 to $0.816 *$ \\
\hline Social impact & 0.645 & 0.541 to $0.735 *$ \\
\hline
\end{tabular}

in OHRQoL related to prosthetic treatment were measurable by the OHIP-EDENT-T (33).

The current study measured both construct and convergent validity of the OHIP-EDENT-T. Previous studies evaluating the OHIP-EDENT used different methodologies for assessing validity, the exploratory factor analysis being the most common $(17,20,21,35,36)$. The main purpose of factor analysis is to facilitate the understanding and interpretation of the relationships between numerous variables considered to be correlated by reducing them to smaller number of basic dimensions. However, even though OHRQoL is generally recognized by the scientific literature to be a multidimensional construct that includes physical and psychological factors as well as social well-being, there is no consensus regarding its specific factorial characteristics (37). Results of the exploratory factor analysis of OHIP-EDENT data varied among studies: Souza et al. (35) reported 4 relevant domains, He and Wang (17), Shrestha et al. (21) and Montero et al. (20) reported 5 relevant domains - with relevancy referring to factors with eigenvalues of $>1$. Possebon et al. (36) is the first study in the literature to report the confirmatory factorial analysis of the OHIP-EDENT instrument. Accordingly, a model was presented with 3 factors comprised of 19 sub-factors. Similarly, the present study found 3 relevant domains for the OHIP-EDENT-T.

This study has a number of strengths, first of which is the wide socio-demographic range of the study population. In addition, the simple language of the questionnaire and scale makes the survey easy to apply and easy to evaluate. In terms of limitations, de novo development was not conducted, so that the final translation could not be compared with previous versions. In addition, sensitivity and responsiveness of the OHIP-EDENT-T could not be evaluated, since this would require a longitudinal study.

\section{Conclusion}

Within the limitations of this study, it may be concluded that the OHIP-EDENT-T is a valid and reliable instrument for evaluating the OHRQoL of edentulous patients.

Türkçe Özet: Konik-ışınlı bilgisayarlı tomografi (kıbt) kullanılarak molar dişlerde kök kanal uzunluğu ölçümü: iki boyutlu ve üç boyutlu yöntemlerin karşılaştırılması. Amaç: Bu çalışmada amaç, büyük azı dişlerinin 2 boyutlu (2D) ve 3 boyutlu (3D) konik-ışınlı bilgisayarlı tomografik (KIBT) yöntemleri ile gerçekleştirilen kök kanal uzunluğu ölçümlerinin, gerçek kök kanal uzunluklarıla uyumunun incelenmesidir. Gereç ve yöntem: 24 büyük azı dişe ait 70 kök kanalı KIBT ile tarandı ve kök kanalları eğimlerine göre "Düz", "Aşırı kurvatürlü" ve "Birden fazla kurvatüre sahip" olarak sınıflandırılmıştır. 2D ölçümler, uygun bir KIBT kesitinde, kök kanalının foramen apikalesi ile ilgili kanalın tüberkül tepesi referans alınarak yapılmıştır. 3D ölçümler, aynı referans noktaları arasında düzenli aralıklarla ilerleyen aksiyal kesitler içerisinde gerçekleştirilmiştir. KIBT ile ölçüm yöntemlerinin tekrarlanabilirlik ve güvenilirlik analizinde Sınıf Iç̧i Korelasyon Katsayısı kullanılmıştır. Gerçek kök kanal uzunluğu ve KIBT ile kök kanal uzunluğu ölçümleri arasındaki farkların kabul edilebilir sınırlar dahilinde $( \pm 0,5 \mathrm{~mm})$ olup olmadığı ki-kare ve McNemar testleri ile değerlendirilmiştir. Bulgular: Her iki yöntemin de tekrarlanabilir olduğu ve mükemmel güvenilirlik sağladığı gözlemlendi. Bununla birlikte, 3D yöntemi ile elde edilen ölçümler \% 85,7 oranla kabul edilebilir sınırlar dahilinde bulunmuştur ve 2D yöntemi ile arasındaki fark istatistiksel olarak anlamlı bulunmuştur ( $p<0.05$ ). "Birden fazla kurvatüre sahip" kök kanallarında, 3D yöntemi ile yapılan kök kanal uzunluğu ölçümleri 2D metodundan daha güvenilir bulunmuş- 
tur. "Düz" kök kanalları için 2D yöntemi "Aşırı kurvatürlü"'kök kanallarına kıyasla gerçek kök kanal uzunluğuna önemli ölçüde yakın sonuçlar vermiştir $(p<0.05)$. Sonuç: $3 D$ yöntemi ile $2 D$ yöntemine kıyasla daha doğru kök kanal uzunluğu ölçümleri elde edilebilinir. Hali hazırda mevcut bir KIBT görüntüsü varsa, büyük azı dişlerinde kök kanal uzunluklarının tedaviye başlamadan önce belirlenmesinde alternatif olarak kullanılabilinir. Anahtar Kelmeler: Konik-ışınlı bilgisayarlı tomografi, Kök kanalı, iki boyutlu, Üç boyutlu, Endodonti

Ethics Committee Approval: This study was approved by the Ethics Committee of Istanbul University Faculty of Medicine (Approval No. 18205).

Informed Consent: Informed consent was obtained from all participants.

Peer-review: Externally peer-reviewed.

Author contributions: $C B$ and $O G$ participated in designing the study. ÖE and KBK participated in generating the data for the study. ÖE participated in gathering the data for the study. SÇD participated in the analysis of the data. $\mathrm{CB}, \mathrm{OG}, \mathrm{KBK}$ and $\mathrm{SÇD}$ wrote the majority of the original draft of the paper. KBK participated in writing the paper. $C B, O G, S C ̧ D$ have had access to all of the raw data of the study. $C B$ has reviewed the pertinent raw data on which the results and conclusions of this study are based. $C B, O G, O ̈ E, K B K$ and SÇD have approved the final version of this paper. SÇD guarantees that all individuals who meet the Journal's authorship criteria are included as authors of this paper.

Conflict of Interest: The authors had no conflict of interest to declare.

Financial Disclosure: The authors declared that they have received no financial support.

\section{References}

1. Islas-Granillo $H$, Borges-Yañez $S A$, Lucas-Rincón $S E$, et al. Edentulism risk indicators among Mexican elders 60-year-old and older. Arch Gerontol Geriatr 2011;53:258-62. [CrossRef]

2. Doğan BG, Gökalp S. Tooth loss and edentulism in the Turkish elderly. Arch Gerontol Geriatr 2012;54:162-6. [CrossRef]

3. Fiske J, Davis DM, Leung KC, McMillan AS, Scott BJ. The emotional effects of tooth loss in partially dentate people attending prosthodontic clinics in dental schools in England, Scotland and Hong Kong: a preliminary investigation. Int Dent J 2001;51:457-62. [CrossRef]

4. Sischo L, Broder HL. Oral health-related quality of life: what, why, how, and future implications. J Dent Res 2011;90:1264-70. [CrossRef]

5. Oh SH, Kim Y, Park JY, Jung YJ, Kim SK, Park SY. Comparison of fixed implant-supported prostheses, removable implant-supported prostheses, and complete dentures: patient satisfaction and oral health-related quality of life. Clin Oral Implants Res 2016;27:31-7. [CrossRef]

6. Carlsson GE, Omar R. The future of complete dentures in oral rehabilitation. A critical review. J Oral Rehabil 2010;37:143-56. [CrossRef]

7. Armellini DB, Heydecke G, Witter DJ, Creugers NH. Effect of removable partial dentures on oral health-related quality of life in subjects with shortened dental arches: a 2-center crosssectional study. Int J Prosthodont 2008;21:524-30.

8. Bae KH, Kim C, Paik DI, Kim JB. A comparison of oral health related quality of life between complete and partial removable denturewearing older adults in Korea. J Oral Rehabil 2006;33:317-22. [CrossRef]
9. Heydecke G, Klemetti E, Awad MA, Lund JP, Feine JS. Relationship between prosthodontic evaluation and patient ratings of mandibular conventional and implant prostheses. Int J Prosthodont 2003;16:307-12. [CrossRef]

10. Inoue M, John MT, Tsukasaki H, Furuyama C, Baba K. Denture quality has a minimal effect on health-related quality of life in patients with removable dentures. J Oral Rehabil 2011;38:818-26. [CrossRef]

11. John MT, Reissmann DR, Allen F, Biffar R. The short-term effect of prosthodontic treatment on self-reported oral health status: the use of a single-item questionnaire. Int J Prosthodont 2007;20:507-13.

12. Locker D. Measuring oral health: a conceptual framework. Community Dent Health 1988;5:3-18.

13. Hegarty AM, McGrath C, Hodgson TA, Porter SR. Patient-centred outcome measures in oral medicine: are they valid and reliable? Int J Oral Maxillofac Surg 2002;31:670-4. [CrossRef]

14. Slade GD. Derivation and validation of a short-form oral health impact profile. Community Dent Oral Epidemiol 1997;25:284-90. [CrossRef]

15. Awad M, Al-Shamrany M, Locker D, Allen F, Feine J. Effect of reducing the number of items of the Oral Health Impact Profile on responsiveness, validity and reliability in edentulous populations. Community Dent Oral Epidemiol 2008;36:12-20.

16. Allen F, Locker D. A modified short version of the Oral Health Impact profile for assessing health related quality of life in edentulous adults. Int J Prosthdont 2002;15:446-50.

17. He SL, Wang JH. Reliability and validity of a Chinese version of the Oral Health Impact Profile for edentulous subjects. Qual Life Res 2015;24:1011-6. [CrossRef]

18. Souza RF, Patrocínio L, Pero AC, Marra J, Compagnoni MA. Reliability and validation of a Brazilian version of the Oral Health Impact Profile for assessing edentulous subjects. J Oral Rehabil 2007;34:821-26. [CrossRef]

19. Sato $Y$, Kaiba $Y$, Yamaga $E$, Minakuchi S. Reliability and validity of a Japanese version of the Oral Health Impact Profile for edentulous subjects. Gerodontology 2012;29:1033-7. [CrossRef]

20. Montero J, Macedo C, López-Valverde A, Bravo M. Validation of the oral health impact profile (OHIP-20sp) for Spanish edentulous patients. Med Oral Patol Oral Cir Bucal 2012;17:469-76. [CrossRef]

21. Shrestha B, Niraula SR, Parajuli PK, Suwal P, Singh RK. Reliability and Validity of a Nepalese Version of the Oral Health Impact Profile for Edentulous Subjects. J Prosthodont 2018;27:416-20. [CrossRef]

22. Bilhan $\mathrm{H}$, Geckili O, Sulun T, Bilgin T. A quality-of-life comparison between self-aligning and ball attachment systems for 2-implant-retained mandibular overdentures. J Oral Implantol 2011;37:167-73. [CrossRef]

23. Geckili O, Bilhan H, Bilgin T. Impact of mandibular two-implant retained overdentures on life quality in a group of elderly Turkish edentulous patients. Arch Gerontol Geriatr 2011;53:2336. [CrossRef]

24. Geckili O, Bilhan H, Mumcu E, Dayan C, Yabul A, Tuncer N. Comparison of patient satisfaction, quality of life, and bite force between elderly edentulous patients wearing mandibular two implant-supported overdentures and conventional complete dentures after 4 years. Spec Care Dentist 2012;32:136-41. [CrossRef]

25. Geckili O, Bilhan H, Mumcu E, Tuncer N. The influence of maximum bite force on patient satisfaction and quality of life of patients wearing mandibular implant overdentures. J Oral Implantol 2012;38:271-7. [CrossRef]

26. Mumcu E, Bilhan $\mathrm{H}$, Geckili O. The effect of attachment type and implant number on satisfaction and quality of life of mandibular implant-retained overdenture wearers. Gerodontology 2012;29:618-23. [CrossRef]

27. Floyd FJ, Widaman KF. Factor analysis in the development and refinement of clinical assessment instruments. Psychol Assess 1995;7:286. [CrossRef] 
28. Zarb GA, Hobkirk J, Eckert S, Jacob R. Prosthodontic treatment for edentulous patients. 13th ed. Mosby/Elsevier, St Louis; 2012.

29. Cronbach LJ. Coefficient alpha and the internal structure of tests. Psychometrika 1951;16:297-334. [CrossRef]

30. Bartko JJ. The intraclass correlation coefficient as a measure of reliability. Psychol Rep 1966;19:3-11. [CrossRef]

31. Bartlett MS. Tests of significance in factor analysis. British Journal of Statistical Psychology 1950;3:77-85. [CrossRef]

32. Fayers PM, Machin D. Quality of life: The assessment, analysis and interpretation of patient-reported outcomes. 2th ed. Chichester: John Wiley \& Sons Ltd; 2007.

33. Duale JMJ, Patel YA, Wu J, Hyde TP. A Systematic Review and Meta-Analysis of Baseline Ohip-Edent Scores. Eur J Prosthodont Restor Dent 2018;26:17-23.
34. Komagamine Y, Kanazawa M, Kaiba Y, Sato Y, Minakuchi S, Sasaki Y. Association between self-assessment of complete dentures and oral health-related quality of life. J Oral Rehab 2012;39:84757. [CrossRef]

35. Souza RF, Leles CR, Guyatt GH, Pontes CB, Della Vecchia MP, Neves FD. Exploratory factor analysis of the Brazilian OHIP for edentulous subjects. J Oral Rehab 2010;37:202-8. [CrossRef]

36. Possebon APDR, Faot F, Machado RMM, Nascimento GG, Leite FRM. Exploratory and confirmatory factorial analysis of the OHIP-Edent instrument. Braz Oral Res 2018;32:111. [CrossRef]

37. Locker D, Mscn EW, Jokovic A. What do older adults' global selfratings of oral health measure? J Public Health Dent 2005;65:14652. [CrossRef] 